\title{
Amazement as a necessary element for a comprehensive formation
}

\section{El asombro como elemento necesario para la formación integral}

\author{
NIEVES-CHÁVEZ, Mayra Araceli†* \& ORTEGA-MARTÍNEZ, María Cristina \\ Universidad Autónom de Querétaro, Facultad de Psicología, México.
}

ID $1^{\text {st }}$ Author: Mayra Araceli, Nieves-Chávez / ORC ID: 0000-003-3934-8090, CVU CONACYT ID: 735591

ID $1^{\text {st }}$ Co-author: María Cristina, Ortega-Martínez / ORC ID: 0000-0002-6188-4677, CVU CONACYT ID: 597320

DOI: $10.35429 / J T E R .2021 .20 .7 .24 .30$

Received July 25, 2021; Accepted December 30, 2021

\begin{abstract}
We will talk about the systematization of the educational experiences in amazement didactics in the Autonomous University of Queretaro. The objective is to comprehend how a comprehensive formation is achieved on the participants in the classrooms based on amazement didactics. The classes were imparted under the didactic strategies of theater, clown, and magic with the goal of fostering amazement in social encounters. The sessions were registered in a class journal. The systematization process consisted of answering the question: How does amazement contributes to the comprehensive formation of the involved in the educational process of the university classroom. The focus of the systematization was thoughtful, it sought to explain how a happy environment was created in the classes. The systematization process was used in the classes at the end of the school year 20201. Amazement uses laughter, looks, silence, and thoughtfulness that wakes up the creativity, foster trust, and create bonds of love, as well as the curiosity to learn in virtual environments in the confinement period brought by the health emergency. This was one of the results found, as well as recognizing that recognition makes us exist and motivates us to be more, humanizes us, achieving a comprehensive education, originating from a participative process that leads to the harmonious development attending all the dimensions of the person, such as the cognitive, affective, community, ethic, cultural for the full humanization of the person, from amazement strategies that lead to think and act from other possibilities.
\end{abstract}

Amazement, Happy environment, Comprehensive formation

\begin{abstract}
Resumen
Se hablará sobre la sistematización de experiencias educativas en didácticas del asombro, en la Universidad Autónoma de Querétaro. El objetivo es comprender cómo a partir de didácticas del asombro se logra la formación integral de las y los participantes en las aulas. Las clases se realizaron bajo la estrategia didáctica del teatro, clown y magia con la finalidad de promover el asombro en el encuentro social. Las sesiones se registraron en un diario de clase, el proceso de sistematización consistió en responder a la pregunta ¿cómo el asombro contribuye a la formación integral de las y los involucrados en el acto educativo del aula universitaria? El enfoque de la sistematización fue reflexivo, se buscó explicar cómo se construyó el ambiente felicitario en las clases. Al final del curso escolar 2020-1 se trabajó en los grupos el proceso de sistematización. El asombro lleva risas, miradas, silencios, reflexiones que logran despertar la creatividad, fomentar la confianza, y crear lazos amorosos, así como la curiosidad por aprender en los entornos virtuales en el tiempo de confinamiento por la emergencia sanitaria, esto fue uno de los resultados encontrados, así como reconocer que sentirnos mirados nos hace existir y motivarnos a ser más, nos humaniza, logrando una educación integral, a partir de un proceso participativo que lleva al desarrollo armónico atendiendo todas las dimensiones de la persona como es lo cognitivo, afectivo, comunitario, ético, cultural para la plena humanización de la persona, a partir de estrategias asombrosas que llevan a pensar y actuar desde otras posibilidades.
\end{abstract}

Asombro, Ambiente felicitario, Educación integral

Citation: NIEVES-CHÁVEZ, Mayra Araceli \& ORTEGA-MARTÍNEZ, María Cristina. Amazement as a necessary element for a comprehensive formation. Journal of Teaching and Educational Research. 2021. 7-20:24-30.

\footnotetext{
* Correspondence to the Author (Email: mayra_marzo6@ hotmail.com)

$\dagger$ Researcher contributing as first author.
} 


\section{Introduction}

\section{From the problem of distance to the need to look at ourselves again. By way of introduction}

The health emergency caused by Covid-19 took us back to the private space, the classroom was moved to the house, and a new way of being a teacher and learner began. The displacement brought with it an unprecedented social distancing, we stopped looking directly into each other's eyes, hugging each other, feeling the proximity of the other, experiencing sensations and feelings in a common space, the possibility of feeling complicity and company in being, as well as educating ourselves in everyday interactions was limited. With this we understood that the school is not the physical place, the walls, the benches, or the chalkboards and markers, but rather the agents who intervene, professors, male and female students. At the same time, it is not only that, but it goes further and the process of education is found in the interaction, the relationships that are established between them.

The distancing, with the passing of time, had effects such as the feeling of feeling isolated, of a general fatigue due to overexposure to the screens, of being oblivious to the other and what happens outside our homes, education as an act of Self-awareness and acting in the world was slowed down, because education is an eminently social act that requires social relationships. How to educate comprehensively on screens? How to weave the fragmented social bond? The didactics and pedagogy had to be questioned.

The conditions in which teaching is carried out in times of Covid-19 invite us to rethink what and how we teach, from imagining how we want to live this time of distancing and what we want to build post-pandemic from the educational act. In person, it was possible to see their reactions to various events, the ways of relating to colleagues, intuiting their emotional states, sharing the vision of the world, in the virtual all this is clouded, screens and microphones turned off do not fully reveal realities, or do it in a more blurred way.
They led us to think more about a selfabsorption, wrapped in the one or in the myself, perhaps in the most familiar and intimate but detached from the other that at the same time builds us and makes us know ourselves, recognize ourselves, in the absence of the other as a retributive mirror we remain like that image without reflection that can absorb us or make us lose ourselves, just like Narcissus drowned in his immobile image because it does not come from the interaction with the other.

How can we re-focus on ourselves and ourselves in an integral way? Education is a relationship between teacher and student, it is paying attention to today to build tomorrow, looking at ourselves and understanding ourselves is going beyond transmitting knowledge, it is forming people, creating community. Teachers must accompany and lead the person to more, for this we must attend to the characteristics and dynamism of the person and respond to it to welcome the other, and entering with this is a movement of generous donation among the actors of the educational act, a possible way out was to educate from amazement, to fall in love with ourselves and with the other, with the world, by looking to grow as people in an integral way.

This document is an exercise in the systematization of educational work on the virtual screen, based on a didactics of amazement to promote comprehensive training and the curiosity to continue learning in a time of uncertainty and social fatigue. The objective is to explain how didactic strategies that invite to imagine, to live the surprise of the present moment favor the knowledge of oneself and of the other, to make a leap towards humanization that allows the transcendence of existence.

\section{Learning to amaze ourselves in order to recognize ourselves: theoretical approach}

Teaching work needs to clarify a transcendent purpose, a why to educate, and to propose a how to educate, which is didactics. 


\section{On the need for conscience: comprehensive education}

The transcendent aim is to attend to the integral or holistic formation of the students, not to leave aside the dimensions, that the knowledge they learn acquires understanding and meaning to transcend the everyday in the personal, social and community context (González, 2008).

Educate from experiences in a dialectical way, what a way that each day is more than it is today. The need to return to oneself and to be able to re-form the collective calls for a holistic education because it is the way to become aware of oneself, to look again at oneself and look at ourselves to act and transform the world from loving relationships with oneself, the other and the world in its entirety, appealing to the totality of being and in harmony with what surrounds it (Gonzáles, 2008 and Gallegos 1999). It is not the mere learning of data, information, or reflection on this, it is an education to know how to do, but also to know how to live, in community. Knowledge that is learned and does not transform the community ends up not being valuable.

What is desired is that the students achieve a vision of full consciousness, which allows the understanding of existence and for this it is necessary to work on the conceptual knowledge that revives their attention to reality and knowledge, as well as their memory and will. Experiential knowledge is needed such as creative, artistic and aesthetic processes that lead to awakening the sensory, the power to taste the world in all its contradictions to promote the wisdom of life from integrating reason and subjectivity, sanity with loquacious. Subjectivity is the way to meet oneself, with the other and their world from looking at oneself and looking at ourselves, expanding their consciousness and knowing themselves alive and in loving company, from creative work and imagination (Gonzáles, 2008 and Gallegos 1999). Holistic education aims to awaken sensitivity, creativity and hope for the transcendence of existence from considering the different knowledge that coexists in the person, for such teaching work a didactics is required that recovers some principles of holistic or integral education such as human development, recovery of experience, the multiple paths to obtain knowledge, an environment of freedom and joy in harmony with oneself, the other and their environment (Gonzáles, 2008).

\section{Didactics}

Didactics is a teaching knowledge, a what and how I want to do it, which is born from experience. Knowing that it is born from the reflection of doing and that is why the path that is traveled to further the teaching practice. The didactics gives meaning to the work in the classroom (Díaz, 2009). On didactics falls the responsibility to meet specific demands of training and teaching, at this time of confinement it is still a priority to put the person at the center, attend to comprehensive training and therefore, a didactics that recovers the sense of the human, feel accompanied, looked at, listened to and reestablish the social bond. By recognizing the need to humanize, it is possible to establish a theoretical guide that allows taking a position before the social problems of the teaching and training spaces and that from how I teach a solution is given from the reflection of a teaching project (Camillioni, 2007). Teachers take a position on how to teach to respond to what happens in the social environment, a position that is born from the reflection of teaching knowledge, didactics is what makes educational work appropriate to social ills.

\section{Didactics of wonder}

Education is an eminently social task and therefore relational, it is given from coexistence, to educate is to teach to coexist (Maturana, 1996), and for coexistence it is necessary to look and become aware of existence, that is the First task in teaching, learning to look, know how to accompany and discover everything that is and can become in each student. A look that enables trust, tenderness, the security in which you can grow together.

Provoking a loving and hopeful look is possible from amazement, looking at the everyday as if it were new, as if it were the first time, re-enchanting existence and finding the "wonderful" in the everyday, making a break from the routine so that what is born new (Chateau, 1966) teaching-learning to look at the world from the complex that brings in itself the contradiction, the striking, enigmatic and loquacious. It is becoming aware of existence. 
Looking at what we always look at from another edge, from a cordial gaze that generates new encounters, from considering the opposites of reality, from experiencing joy in pain, silence in the bustle, hope in disappointment, these opposites that allow us to experience other possibilities is what triggers the astonishment (Chateau, 1966). Thinking and living in opposites, like a roller coaster ride, is what makes the world question and seek new possibilities of being in the world, it is right there where the veil of habit is torn and the world is reorganized and the dam is broken from disenchantment to start the new, taste the tenderness, trust, community, loving care and create new frames of social interaction with oneself, the other and the world. It is to reorganize the world from the social and individual conscience, in dialogue and trust.

\section{Teaching-learning strategies from amazement}

Teaching-learning strategies are actions to be followed to achieve objectives and attend the teaching-learning process, they are procedures to show and process academic content. They are bridges for mental processing to the student's attitudinal according to learning objective (Monereo, 1998). The strategies are general action programs with a specific action resource, which gives meaning to the teaching-learning task, these are chosen from the awareness of what is to be taught according to the learning situation and climate (Monereo, 1998).

Learning is an individual task but that occurs with the support of the collective, experiential learning, such as tenderness or joy, they need to go beyond routine, fear, loneliness and open up to love and trust, theater is a form to awaken the imagination, to stimulate the senses, to set the body in motion, as well as to empathize when it comes to interpreting the character, by putting oneself in the place of the other, unthinkable feelings, emotions, ideas and realities are experienced. The theater helps to feed creativity with the creation of characters, stories, stimulates concentration and understanding through dialogue, but also to look at what the other does to interpret messages, in the ways of expressing feelings. It is a strategy that stimulates the expression of the body, the affective in the empathy process, the cognitive when interpreting, the social because selfconfidence is consolidated and ideas are socialized (Vittar, 2015).
Theater is building the world from the game of being what one is not, from a cognitive and sensory knowledge.

Magic as a didactic strategy breaks monotony and gives moments of astonishment, makes us believe that the impossible is possible, sows the illusion of creating new possibilities. It helps students to believe in their creative power, in their ability to start over, to reflect on possible ways, to investigate new paths, to move away from the known to explore the new. Magic makes the known look from the amazing, from hope, joy and creative and innovative expression of the world and from the person himself (Ruíz, 2013). To do a magic trick is to look at and create the world again. An action that favors concentration, memory, judgment, but also the sensory and therefore is integral.

Finally, the Clown is to narrate the tearing of life from the comic point of view, it shows us what we are fleeing from and reconciles us with a look and a laugh or complicit silence. The clown looks and makes us look, listen and be attentive to himself to recognize the interior and what is lived and thought is conscious presence, living the present moment from the pleasure, the internal joy that gives to put the right place in the painful life experience (Velásquez, 2019 and Dream, 2020). The clown is to take back the human essence and at the same time mirror the other, I look and they look at me, I listen and they listen to me and from laughter we build the new, we recognize what we like, yearn for and love. A holistic knowledge that favors the consciousness of being.

\section{Steps taken: systematization of educational practices}

Didactics is a teaching knowledge, which is born from the reflection of how to give meaning to educational practices, hence the need to systematize to improve and increase teaching knowledge, it is a way of interpreting the contexts in which the task of teaching is developed. teach, make a work proposal that responds to social needs (Camilloni, 2007). The systematization is a critical look at educational work to generate new knowledge, identify areas of opportunity, recover experience that achieve transcendent ends, because it is a knowledge that is born from community reflection (Jara, 2017). 
The systematization approach was reflective, it sought to explain how the happy atmosphere was built in the classes, what actions and strategies helped to grow as a person and therefore have a better school environment. The task of systematizing the teaching practice began with: a) the elaboration of an educational program that would collect the needs of the students and the reflection of the previous semester that would serve for the elaboration of training objectives and if they were linked to the contents and activities of the program, 2) bibliography review, 3) be clear about the levels and moments of each astonishment activity to educate the gaze, 4) community reflection on how they lived the process that allowed or hindered a happy or joyful atmosphere in the classroom space.

\section{Class diary}

Methodological tool used to document the daily events of the class, all those situations that occurred during the teaching-learning process were recorded, description of the context and setting of the practices, of the teaching-learning sequences in space and time of the actors of the educational act (Zabalza, 2004). It was a tool that served to understand how the astonishment favored the creation of a festive atmosphere of trust and the desire to share in an integral way. Actions, topics addressed and daily learning were collected in the diary. The records were made in three groups with the same didactics of two different educational programs in health and education, the students corresponded to semesters of fourth and eighth semesters.

\section{Analysis Categories}

The categories were built from community reflection and from the one collected at the end of each class from the question, how does amazement build a happy environment for integral education?

The categories werea.

a) Gaze-silence-silence gaze.

b) From gaze to love.

c) Group consciousness.

Each category is a step in the educational process.

\section{Results}

The astonishment strategies bring with them the possibility of looking differently, alternately, and with it the experience of coexistence with oneself and the other from the love before the trial and establish empathic bonds to go through the experience of being alive in the company. It is possible to discover the being, to be able to be and from there transform an active process into integral education.

\section{Look-silence-silence-look: to be}

We arrived at a virtual class with different rhythms and eagerness, looking is not an easy job, the screen is our own reflection that clouds the presence of the other, in others we look by hierarchy as is the case of the person who teaches the class. "We feel like a group again when each one was giving a creative greeting with gestures, sounds and words looking at the camera, because we felt that we existed for the other one" one of the conclusions of how festive spaces were made, to watch we had to remain silent, a complicit silence waiting for a word and gesture.

Other moments that regained their gaze were "The moment of presenting the works with the puppets, we discovered creativity, skill, topic of interest and thinking about their effort to share something well done, led us to pay attention to their work, and then think in the same way they looked at us". The look requires silence, concentration on the gesture, movement, words, being amazed by the presence of the other. Learning is the need for silence to live a moment of encounter, silence is only possible in the liberation of time to concentrate on what appears in front of us.

For integral education, the first thing that should be favored is silence, as reflection, as an encounter that welcomes the presence of the other through looks, concentration in the present moment (González, 2008, and Le Bretón, 2016). "We have learned that they look at us to rate a job, well done or badly done, but when looking at it was to laugh at what the other did, surprise us at their occurrences and their work, and to make suggestions for improvement, it was to recognize that we have potential and we are growing, it motivated us to continue. 
To look from amazement is to know that we can be more, to highlight the beauty that exists and to recognize that the more being has things to work on, but not from the judgment, but from the acceptance and judgment of itself in its proper measure.

Comprehensive education seeks to string together all the dimensions of the person, the gaze is the mirror where the essence of oneself is discovered, in silence it is reconnected with the interior and all the knowledge that is fragmented comes together and makes sense, a concept finds its usefulness in reality, a feeling clothes it with utopias, and a movement of the body awakens the transformation of itself and the world. Silence and gaze is the first step to knowing and recognizing the other through love, because they are the cradle of existence.

\section{From the look to love: to be}

After the look comes love "When we look to enjoy we find unimaginable things about the other, and then when others look at us and see beautiful things in one, we did not want to turn off the screen because we were enjoying a lot" Love is born of recognition, from amazement, from the uniqueness that leads to the desire to accompany and be accompanied, it is right here where the first sparks of conscience are born.

The feeling of being accompanied arises with a simple gesture that changes our lives, putting on a red nose leads to the openness of feeling and being in the world, such as spontaneity, curiosity, and living in the present. The use of putting on a red nose leads the game to disinhibit and let the authentic self emerge without judgment or prejudice. "The ritual of putting on our clown nose and committing ourselves to enjoy ourselves led us to investigate emotions, because we did not know what they were and how they manifest themselves, but the best thing was to laugh at seeing them act because something of that happened to us or had happened to us and to see the way out they gave him helped us to be creative in life or simply to enjoy what we are living". Love is born from amazement and from affirming ourselves, a congratulatory space that then gives way to internal dialogue to foster love in its proper measure. A red nose is a bridge for a small mask that makes breastplates fall, being hospitable to the other from the game without judging.
Recognizing that emotions make us do, say and think things from comedy and improvise life from laughter and play leads to a realization of who and how I am, it is the consciousness of oneself, of how I am in the here and now and with the reality that surrounds me. The other is a mirror of one's own reality and finding oneself in the same dilemmas of life fosters love, possibilities of meeting and learning to live together from acceptance (Maturana, 1996) and finding a sense of life and founding new habits of social interaction for growth, autonomy and interdependence (Patiño, 2010). Self-awareness is recognizing what I feel, think, do and want to do, to then be intention from a genuine interest. Artistic work emancipates and humanizes by reading and resignifying daily life (Gardner, 2011).

\section{Social awareness: act}

Comprehensive education goes beyond selfawareness, but appeals to social awareness, living from useful habits to others, being responsible for the common future "At the end we are left with the feeling of being a community, of having grown in confidence, to take care of what we say and do for the good of the group ", is to grow not only in intelligence or knowledge but also in an affective way, to recognize that we feel involvement with each other and that for such reasons think about more transcendental things such as justice and justice. solidarity, that recognizing and living the feeling of love makes life happy because it injects hope, joy, trust. Comprehensive education is possible when we look at ourselves, and by looking at ourselves we recognize ourselves from compassion, to be aware of existence and recognize interdependence with others and through them we want to make life happy.

\section{Considerations}

Comprehensive education is an invitation to taste life in communion with oneself and with others, to recognize that we are thoughts, feelings and actions, that we humanize ourselves in coexistence. That which limits us to living flatly human in denying ourselves with the look, being afraid, competing with the other or envying, because they do not give way to knowing the beauty that is in each one of us, and only in the loving and empathetic look can there be acceptance of oneself and of the other. 
Learning under this integral view occurs when we transform the gaze of ourselves and of what is external to us.

Simba and Mufasa's conversation from the Lion King reminds us of the mission of holistic education with the following dialogue: Mufasa: Simba, you have forgotten me. Simba: No, never that. Mufasa: You have forgotten who you are, therefore you have forgotten me. Look inside Simba. You are more than you are now. You must take your place in the cycle of life.

Education must be a reflection of what we think, desire, and express our opinion in order to be rethought, analyzed, questioned and rebuilt, to be more and better, to live again from joy and commitment.

The astonishment strategies modify the coexistence and the treatment with oneself for more loving and congratulatory experiences from academic reflection and sharing with the other for integral formation by questioning the thinking, feeling and acting from the contradiction of the moment to give feel and act , to give way to new constructions of knowledge and broaden the horizon of understanding the world (Litwin, 2013), to transform, or at least to rehearse new forms of relationship with the world, to live the tension, joy and possibility of experiencing forms alternates of being and achieving human development, this being a process of comprehensive humanizing and congratulatory training.

\section{References}

Chateau, J. (1966). Filosofía y política de la educación. Buenos Aires: Nova

Camilloni, AR.W. (2007). El saber didáctico. México: Paidós

Díaz, A. (2009). Pensar la didáctica. Buenos Aires: Amorrortu

Dream, C. (2020). Apayásate. España: Clownplanet

Gallegos, R. (1999). Educación holística. Pedagogía del amor universal. México: PAX México

González, A.M. (2008). Educación holística. La pedagogía del siglo XXI. Barcelona: Kairós
Gardner, H. (2011). Educación artística y desarrollo humano. Barcelona: Paidós

Jara, O. (2017). La sistematización de experiencias: práctica y teoría para otros mundos posibles. Colombia: CINDE

Le Breton, D. (2016). El silencio. Aproximaciones. Madrid: Sequitur

Litwin, E. (2013). El oficio de enseñar: condiciones y contextos. Buenos Aires: Paidós

Maturana, H. (1996). El sentido de lo humano. Santiago de Chile: Dolmen Ediciones

Monereo, C. (Coord). Estrategias de enseñanza $y$ aprendizaje. México: SEP/Biblioteca del Normalista

Patiño, H.A.M. (2010). Perona y humanismo. Algunas reflexiones para la educación en el siglo XXI. México: Universidad Iberoamericana

Ruíz, X. (2013). Educando con magia. El ilusionismo como recurso didáctico. Madrid: Narcea

Velásquez, A.M. (2019). Encontrar el propio clown: Ejercicios prácticos para la búsqueda de su payaso. Colombia: Universidad de Antioquia

Vittar, D. (2015). Didáctica y práctica del teatro en la escuela. Buenos Aires: Bonum

Zabalza, M.A. (2004). Diarios de clase. Un instrumento de investigación y desarrollo profesional. Madrid: Narcea https://drive.google.com/file/d/1dHWnrA2nKx AxVDn_gpPttjgy55gYi1qd/view 